\title{
THE CONTESTATION OF ACTORS AND CONFLICT ESCALATION IN GOLD MINING AREA OF SOUTHWEST MALUKU REGENCY
}

\author{
Pakniany Yamres*, Sapulette Alce Albartin \\ State Christian Institute of Ambon, Indonesia \\ *E-mail: ypakniany@gmail.com
}

\begin{abstract}
Indonesia is one of the largest countries with natural resources wealth scattered on land and at sea. The natural resources wealth owned is beneficial to improve the state economy and the people welfare. The management and the utilization of the natural resources are expected to provide benefits for all people scattered in the territory of the Unitary State of the Republic of Indonesia, including in Southwest Maluku Regency, Maluku Province. Gold mining is the wealth owned by people in Southwest Maluku Regency, precisely in Romang Island. The management and the utilization of the gold mining have not been able to improve the welfare of the people, but instead it creates conflict among actors. The conflict among actors that occurred was caused by differences in interests on gold resources. As the result of the conflict, social relation among the people was broken, and at this level, the possibility of conflict escalation will occur. This research uses qualitative method with case study approach. The purposes of this research are to analyze the conflicts among the actors and the possibility of the conflict escalation. The results of this study indicate that the conflicting actors are the state, the private and the people, while the possibility of conflict escalation is due to the creation of social class structure and the weakening of cohesiveness in the society.
\end{abstract}

\section{KEY WORDS}

Conflict, gold mining, actor, escalation, Southwest Maluku.

The development of the mining industry in 1970 in Indonesia helped increase the role of the mining industry to meet the domestic and the foreign needs. Various commodities are processed from the mining of oil and natural gas, coal, tin, gold and silver, as well as minerals such as sand, river stone, limestone, which is also followed by the growth of the management and manufacturing of finished goods industries. The impacts of the mining industry vary greatly depending on the type of commodity and its spreading characteristics. In addition to the environmental impacts, mining activities may also have social, economic and criminal impacts (Sudrajat, 2006) as well as conflicts.

The impact of the management and the utilization of natural resources (NR) by mining occurred in various regions in Indonesia, one of them is in Maluku. Maluku lies between the confluence of three main plates forming the earth's crust namely Eurasia plate (north), Indonesia Australia plate (south), and Pacific plate (west), which is a potential area for the formation of various mineral reserves, geothermal, and hydrocarbon basins. The mining potential and the potential energy to be developed commercially i.e gold, copper, nickel, limestone, sulfur, petroleum, and geothermal energy are located in various regions of Maluku Province (Hanafi, 2012). NR owned by Maluku also provides benefits for the society, but also presents problems of social, economic, health to criminal acts that culminate in conflict. Humanitarian problems (social, economic, health, to conflict) also occur in Buru regency, Maluku Province. The traditional mining extractive process that has taken place since October 2011 in several places in Buru regency, Maluku has created many problems, such as population growth, environmental damage and pollution resulting in health quality, prostitution to horizontal conflicts (Hasyimi et.al, 2014).

In addition to Buru regency, there is also one regency in Maluku which is experiencing mining problems, namely Southwest Maluku Regency, precisely in Romang Island. Romang Island is one of the small islands rich in natural resources with an area of $1129.6 \mathrm{~km} 2$ 
covering: land area of $192.20 \mathrm{~km} 2$ and sea area for regency governance area (0-2 miles) of $465.8 \mathrm{~km} 2$ and provincial governance area (2-4 miles) of $472.6 \mathrm{~km} 2$, with the length of coastline $121.76 \mathrm{~km}$ (Directory of Small Islands, 2012). The land fertility owned by this island has positive impact on the people. Superior commodities such as: forest nutmeg, super nutmeg and cloves are the types of plants living on the land of Romang Island.

In addition to these commodities, the land of Romang Island also holds wealth of gold which is abundant. The wealth of NR owned by Romang Island also provides benefits and improves the economy for the people, however, the wealth of natural resources is no longer provides benefits to the people when the mining corporations that manage and utilize the gold resources in Romang Island come. PT GBU is a subsidiary of Robust Resources Limited from Australia which had explored gold mine in Romang Island since 2008 until 2016 with land area $9000 \mathrm{Ha}$ of total $17,500 \mathrm{Ha}$. The exploration activities are centered in one of the villages on Romang island, i.e the village of Hila. The extractive activities conducted by PT GBU did not have positive impact on the local people. Since the operation of PT GBU from 2008-2016, it had not been able to improve the welfare of the people. But what happened was conflict that breaks the people relationship. Romang Island people split into two groups, namely the pro-mining group and the group that contra against the mining.

In general, the conflicts happened in mining areas, related to differences in the concept of property and other resources, are the conflicts involving society with companies and companies with the state. The research results of Dimas et.al (2014) showed that mining activities conducted by PT Mahakam since 2009 in Marangkayu Sub-district, Kutai Kartanegara Regency are not fully run smoothly without any conflict. The activities spawned land dispute conflicts between PT Mahakam and people around the mining site. The status of the land that becomes the working area of PT Mahakam in accordance with its work contract is Forest Area, in which to operate in the region PT Mahakam has obtained the permission from the Ministry of Forestry. However, the people around the mining still maintain that the land is their customary property.

Another study was also raised by Ahmad (2014) on the conflict that occurred in the gold mining area of Balaesang Tanjung Sub-district, Donggala Regency, the conflict involving the community and the company namely P.T CMA. The presence of P.T CMA triggered the residents protests, because the mining concessions acquired impacted on thousands hectares of the residents' gardens including coconut, cloves and other short-term productive crops. From generation to generation the plantation has become the source of life of the people who depend their lives on nature, land and water of the region. This is exacerbated by land tenure actions by the companies that prohibit the communities from doing gardening activities on the lands of mining concessions.

Conflict in the gold mining area of Romang Island, Southwest Maluku is not different from conflicts in other areas. The conflicts that occur are inter-actor conflicts caused by different interests in utilizing the region's gold resources. The conflicts undermined the social fabric of the society that had been created long time ago. Mutual respect and help are no longer the basis of living together, but what happen is hatred and vengeance. In this context, the possibility of conflict will be widespread. Based on this background, then the formulation of this research problem is, how the conflict among the actors in the gold mining region of Southwest Maluku Regency can happen? The purpose of this study is to analyze the conflicting actors, conflict typology and possible escalation of conflict.

\section{METHODS OF RESEARCH}

The method used in this research is qualitative with case study approach based on critical paradigm. The critical (subjectivism) paradigm can be used to dismantle the problem of power relations and the contestation of actors underlying the patterns of authorization, utilization and ownership of natural resources. This study is located in the mining area of Romang Island, Southwest Maluku Regency. Informants who become the objects of this study are Romang Island people in conflict and the stakeholders who are related to the management and utilization of the gold resources. The data used in this study are primary 
and secondary data. Primary data were obtained from in-depth interviews, while secondary data were obtained through literatures related to this study. This study lasted for five months, from January-June 2018.

\section{RESULTS AND DISCUSSION}

Actors Contestation toward Gold Resources. The management and the utilization of gold resources in Romang Island, Southwest Maluku Regency also give rise to vertical conflicts involving three actors. The three actors, the state as the first actor, the private (corporation or company) as the second actor and the society as the third actor who always vulnerable against injustice, due to the power of the first and the second actors. Each actors has their own power. The first and the second actors are the actors of power and the capital owners who have the highest authority in making decisions related to the management and the utilization of a resource, while the third actor is the actor who always feels the impact of the management and the utilization of a resource.

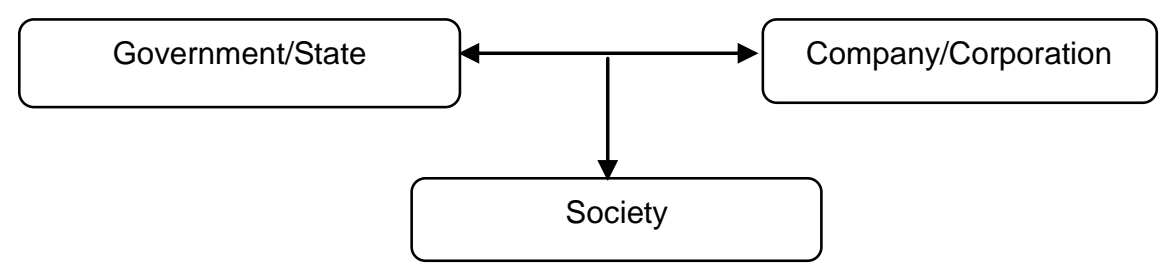

Figure 1 - The contesting actors

Figure 1 shows clearly the position, the power and the relationship among the actors. The government or the state and the company or the corporation are the two actors who have power relations (main actors (Emenyeonu and Bahtiar, 2017)). The state as the holder of the highest regulation and the company as the manager and the utilizer of natural resources can not be separated. Therefore, the company will need the state as mandator of the implementation of a mining activity through the granting of licenses by referring to regulations, and the state will need the companies in managing the natural resources. In principle these two actors will support each other and will not harm one party. Sometimes, both actors also use their power to intimidate society and eliminate the society from their ownership, either individually or in groups. To achieve their goals, they will use any ways, so that their goals can be achieved. Thus, the society frequently serve as commodity.

The actors involved in the utilization of natural resources in the gold mining area of Romang Island are state, private and local people. The state or the government in question is the government of MTB and MBD regency, the government of Romang Island Regency and the government of Romang Island sub-district. These actors have the power to grant permission to the company to conduct mining activities in Romang Island. Without these actors, the company (PT GBU) will not come to the territory of Romang Island and perform extractive mining activities. The highest regulatory holder is in the hand of the state, then the licensing process related to the presence of PT GBU becomes the task of the state. Of course, each actors has their own interest in the management and the utilization of gold resources in Romang Island.

The corporation or company, as the second actor, also has significant role in the management and ther utilization of gold resources in Romang Island. Because the corporation, in this case PT GBU, is the company granted permission by the state to manage and utilize the gold resources. In the process of exploration, PT GBU has pocketed various permits from the government of MTB and MBD regency as well as the permission of the government of Romang Island Sub-district. However, PT GBU still disturbs the people with its presence. Local people as the owners of these resources, often intimidated for the achievement of the company interests. In fact, if the management and the utilization of the natural resources is done by accommodating the needs and the interests of the society, the society will accept the presence of PT GBU widely. 
The local people as the third actor also has an interest in the management and the utilization of gold resources. The society want transparent management process and accommodate their interests and needs. But this hope is gone, because what is expected does not match the reality faced. The society tend to be ignored from their property rights. As the low class society and do not have power to defend their rights, they only follow what the government and the company do. Government powers and authority are used to marginalize the society. Nevertheless, people are still seeking solutions to their rights by fighting against the policies decided by the government and the company, even if finally it is unsuccesful. The resistance is continued, to the extent that society split into two groups and horizontal conflict occur.

Each actors has different capabilities in accessing the resources in Romang Island. Such access in the perspective of Ribot and Pelusso (2003) is a collection of power more emphasising on "the ability to use" rather than a cluster of rights. In addition, access can also be seen in a broader relationship, which can make individuals or society communities gain benefits or profits from the resources, even if they do not have property relationships. In line with the views or perspective of Ribot and Pelusso, it can be said that the actors concerned with the gold resources in Romang Island have the power to utilize these resources. Especially the state and the private, who do not have property relationships, but because of their strong regulation and access, then they can access the gold resources in Romang Island. Thus, access to a resource is not measured by the ownership of a property, but the extent to which the power in accessing the property is owned.

Conflict Typology in the Gold Mining Area of Romang Island. Fisher et.al (2001), divides the types of conflict into three, namely latent conflict, open conflict and surface conflict. Of these three types of conflict, the ones occurred in the gold mining area of Romang Island is latent conflict and open conflict. Both types of conflict can be seen through periodization of conflict over the time. The conflict in Hila Village began in 2008 when PT GBU started to do drilling activities. In the beginning of operation, the process went well in accordance with the expectations of the society. Because there was recognition from the government that the land was owned by matarumah, so the process was allowed to run. Such recognition strengthened the society to let PT GBU continue to operate. Then, at the beginning of 2010, the extractive activities conducted by PT GBU were still being carried out and the process was running well. But in the mid-2010, there had been deviation in the process. The principles of mutual agreement between the people and the government, and even the company, were changing. There were certain actors who began to take advantage of the process. There were unilateral claims against some mining areas conducted by certain actors. This one-sided claim, then triggered suspicions of the society against the government and PT GBU.

In 2012 the suspicions began to reach the peak. The people began to suspect village leaders about the compensation fund and the payment fees for the drilling points that were not felt by the people. This year, conflict began to happen, because PT GBU continued to do their activities and did not appreciate the indigenous resource owners. Conflict continues to occur, but its nature was still latent or hidden. In 2015, the nature of the conflict began to open, where people began to fight against the policies of the village leaders and PT GBU. These policies were related to plant-growing payments and compensation and labor costs. In 2015 there was also split within the society, where the society were divided into two groups, the pro-mining and the contra mining groups. Conflict continues to rise, each society group retained what they wanted and continued to fight. On October 2015, the Governor of Maluku issued IUP-OP (Mining Operation License-Production Operation) to PT GBU to continue their activities. However, this was opposed by the contra group along with a number of the society leaders and NGOs by saying that PT GBU could not perform its activities anymore, because it had polluted the environment. In addition, due to the people dissatisfaction with the management of PT GBU, the community firmly refused PT GBU to continue its activities.

In 2017, conflicts began to grow and led to physical destruction. This year, the Governor of Maluku issued a temporary closing permit for PT GBU activities again, while waiting the second study conducted by a joint team of mining inspectorate and experts team 
of Universitas Patimura. The joint study team from the mining inspectorate, environmental experts and experts team of Universitas Patimura was again revealed to conduct research, in order to verify the results of previous environmental impact studies. This was the periodization of conflict that occurred in the gold mining area of Romang Island. The Periodization of Romang Island conflict, indicates that the typology of conflict is largely determined by the time of the conflict happened. Therefore, conflicts need to be disclosed based on the time of the conflict, thereby facilitating the accommodation of the conflict to be undertaken.

The Possibility of Conflict Escalation. Basically, conflict is affected by the opposing interests between the two sides (Kriesberg, 1998). The conflicting parties will defend their interests as a truth and strive to achieve its objectives. This is what then gives rise to tension and violence between the parties in conflict. At this level, there is likely to be an escalation of conflict that has impact on the social, economic and cultural life of the community. Prayogo (2008) explains that the pattern of conflict escalation can be measured from the level of violence consisting of six levels, in two categories, namely: (1) oral categories (unrest and complaints), (2) action categories (reports, pressures, threats, to murder). The escalation of conflict is also caused by the increasing interest of each groups or parties involved in the conflict (Krisberg, 1998 and Prayogo. 2008).

Two categories of conflict escalation patterns stated by Prayogo (2008) also occurred in the gold mining area of Romang Island. Oral categories in this case unrest and complaints are part of the perceived by the Romang Island community.

Complaints and anxiety are caused by three factors that comprise of (1) the difference factor of the property concept, (2) the cost of compensation and (3) the recruitment of labor. These three factors become people anxiety and complaint, since there are violations committed by the village government along with the company concerning the source of the mine (land), the unfulfilled compensation costs and the costs of compensation that are not in accordance with the wishes of the community, as well as the recruitment of local labors that is unilaterally undertaken by the village government and the company, without involving the customs leaders. The action categories in the form of reports, pressures, threats are also experienced by people who contra against PT GBU. The customs leaders are sued in relation to land disputes. There are threats given to those who are not pro-mining and they are pressured to give their lands and commodities that are the economic sources for their survival. Reports, pressures and threats experienced by communities contra mining are conducted by the stakeholders in the village and the company accompanied by the presence of the security personnels assigned to the gold mining area of Romang Island. The intimidations continue felt by the community, because they do not want to give their lands to PT GBU.

The possibility of widespreading conflict will occur if two categories of conflict escalation patterns and the factors described continue to be experienced by the community. In addition, there are other possibilities that will become new factor in the widespread of vertical and horizontal conflicts that occur in the gold mining area of Romang Island. The new factors are the creation of social class structure of the society and the weakening of community cohesiveness. These two factors will be part of the conflict escalation in Romang Island, if PT GBU continues its activities up to the stage of production, without any conflict accommodation made. The Romang Island people who contra against the mining, remain in their principle, that PT GBU should stop its activities. Because people fear their resources will be threatened and their generation will not be able to enjoy the natural resources. People still believe that nature and everything in Romang Island are gift from God Almighty, which must be preserved for their and future generations of Romang Island sake.

"This nature, God gives us to be managed for our present and future generations. Therefore, we must preserve it" (LS).

The recognition presented by LS is a hope, that the nature of Romang Island must be maintained and preserved for their present life and the future generation of Romang Island. Because, if the nature of Romang island is not maintained and preserved as well as protected from the hands of the irresponsible people, then the Romang Island generation can 
not survive. Nature is not just a life of Romang Island people. Nature is the identity of life that has been inherited long time ago by the ancestors which must be preserved its sustainability. The tone of hope from the Romang Island community continues to be shouted to the stakeholders to dismiss PT GBU activities. However, the voices were not heard by the policy makers in Romang island. Complaints and anxieties felt by the community, even lead to horizontal conflicts that breaks the harmony of community life and ruins the culture and identity of the Romang Island community.

The Creation of Social Class Structure of Society. One of the factors that can lead to the escalation of conflict in the gold mining area of Romang Island is the creation of class structure of the society. The creation of this class structure, due to the access in utilizing the gold resources by each actors. Each actors tries to exert all their capabilities to get benefit from the management and the utilization of gold resources in Romang Island. The ability possessed is used to claim the source of the mining on its own and ignore the other party. Power networks are set up to gain support from the stakeholders, making it easier for the actors to access the gold resources, and ultimately creating social class in the society. The creation of social class in the society is motivated by many factors. However, the most dominant factor is the amount of capital owned and most importantly the access to the land that is the primary measure determines the class position (Breman, 1995). Similarly, Saptari and Holzner (1997) also suggest that the most important resources in the countryside are the land and the specific forms of relationships between members of different social groups. It is this land resource that generates the deferment of rural society and gives birth to a new social class. This view is in line with the community context in the gold mining area of Romang Island. The structure of social class in Romang Island society has been established since a long time ago, but with the passage of time the class structure has been reduced when the community has known education accompanied by the entry of religion. The social class distinction is no longer separator among societies, where there is mutual respect while remaining guided by cultural values.

The social class was again present, when PT GBU came with the aim to manage the gold resources in Romang Island. The society was then fragmented because of the different interests of the existing gold resources. In addition, the unilateral claims on mining resources also re-shaped the social class structure that had long ceased to prevail. The communities were divided into certain classes and the land was used as commodity to which they were opposed. Each class struggles to defend what for them was true and frequently the class group that had power in society, used its power and authority to execute the class groups that did not have power and authority in society.

The social class formed in the life of the Romang Island community, consists of three classes, namely: first, the upper class consisting of the landlord or lord of the island in this case is matarumah Orleta. Matarumah Orleta is matarumah which has full rights to the land resources in Romang Island (Jerusu, Hila and Solat villages). This Matarumah also has the right to divide Romang Island and determines who has the right to eat and drink on which land. Second, middle class consisting of mararumah Kwiatu, Larwoni and other matarumah. These two matarumah and other matarumah are the extensions of matarumah Orleta to organize the people of Jerusu and Hila. Third, the lower class consisting of migrant communities from other islands, such as Kisar Island. This class is the people who are fully under the supervision of matarumah Orleta. Each classes has different access rights to the gold and land resources of Romang Island.

The segregation of classes in the countryside and in particular the mining area will continue and make the conflict more widespread when the people who has power keep suppressing the powerless people. Furthermore, the formation of class structure and the greater distance among rural communities, are not only due to the relationship among them and their relationship to land resources, but also related to the influence of the state and mining companies (Judge, 2015). It is also suggested by Shohibuddin et.al (2010) that, the great influence on the formation of classes, occurs due to the external factors of society i.e the state with its policies and companies that come to control the land resources of the 
community. This condition perpetuates the conflict in the gold mining area of Romang Island and will even have an impact on conflict escalation.

The Weakening of Community Cohesiveness. The second factor that can be the cause of conflict escalation in the gold mining area of Romang Island is the weakening of community cohesiveness. The weakening of community cohesiveness occurs as the result of the changing of social, economic and cultural conditions due to the interests of each groups to the gold resources and its management. However, to know clearly the social cohesiveness of Romang Island people, it is necessary to explain first the social, economic and cultural conditions of the Romang island people before the presence of PT GBU.

The Romang Island community was once a community that lived and was bound by nature. The natural resources on Romang island provide many benefits to them, both onshore resources and marine resources. Considering most of the Romang Island people livelihood are as farmers and fishermen, nature is a gift to them. As a gift, nature must be kept and preserved for survival, both for present and future generations. Life sharing and helping are the basis for Romang Island community. Social, cultural, religious and economic life are established well one another, reaches to the outer village and island. It is this cohesiveness that makes the people of Romang Island far from conflict that causes them to split. The cohesiveness is built on the basis of equality without questioning the social class. Although in the past there was social class, but it did not affect massive to the life of Romang Island community, before the presence of PT GBU.

"In the past, before PT GBU came, we lived well with each other. Nobody said that he was a landlord, and had authority. We all living in Romang Island were the same" (ST and $A P)$.

In the sense that, prior to the presence of PT GBU, the people of Romang Island lived in peace with each other. No one claimed to be a land or island owner, because everyone was the same. Social life was well-created, mutual help in building houses, creating new gardens, manifested from Rosna and Ina-nara as well as Ama-hiyali cultures practiced well. In addition, the community economy was still in the category of enough, because the utilization of the existing natural resources well and without being bothered by others. Communities freely accessed the natural resources such as firewood, timber to build houses, honey production and others for their survival, without being restricted by others. However, after the presence of PT GBU, the cohesiveness of the society was changing. Unilateral claims were made against the mining sources and the benefits of its management. At this point, there was conflict of interest by each actors or parties leading to conflict.

The presence of PT GBU changed the cohesiveness of the society in various aspects of life. Mutual respect was no longer the foundation of living together. Nature that had become a blessing turned into a curse, because of the struggle over the existing resources. The tradition of helping each other was further eroded due to personal interests were preferred to the common interests. Each parties, both the pro and contra looked for solution to keep what was in their interests. If this continues to be allowed, then the possibility of the conflict escalation to the civil war can occur.

This is stated by some informants in Romang Island, especially the informants who are contra against the mining. In the interviews, it was found that, if PT GBU did not get out or leave Hila and Romang Island in general, then what happen is conflict of siblings. This recognition indicates that public resentment against village leaders, PT GBU and pro-mining communities has grown up. It is the resentment that makes the entire society who are contra against the mining get angry and decide to fight against his own brother, if PT GBU does not get out from Romang island.

\section{CONCLUSION}

The contestation among actors in the gold mining area of Romang Island, Southwest Maluku Regency occurs due to different interests regarding the management and the utilization of gold resources. The contestation of the actors, resulting in social life relationship among people in Romang Island. Each actors tries to defend their interests. The possibility of 
conflict escalation to occur, if each conflicting party keeps their opinion on the issue of the mining source and the management as well as the utilization of the existing gold resources. The possibility of the existence of conflict escalation is caused by two factors, namely the the formation of the social class structure of the society and the weakening of the community cohesiveness factors.

\section{SUGGESTIONS}

The important step that must be taken in the management and the utilization of natural resources is the step of collaboration among the stakeholders. Collaboration step is done with the aim to avoid the possibility of conflict to occur, due to deviation from the management and the utilization process of the natural resources. The collaboration among these stakeholders will help the government, the private and the community in agreeing on the rules related to the management and the utilization of natural resources, such as the rights of natural resources ownership.

Prior to the issuance of the permit by the state as the highest holder of the regulation to the corporation as the manager, research must be conducted prior to the social, cultural and economic conditions of the community. This is done with the aim to know the context of the community, so that the policies taken in relation to the management and the utilization of the resources can be done by taking into account the local context of the community, so that there is not deviations that can result in extractive mining activities and also in the community activities.

\section{REFERENCES}

1. Breman, Jan. (1995). Work and Life of The Rural Proletariat in Java Coastal Plain. Pp. 144 Modern Asian Studies. Great Britain.

2. Bryant, Bailey. (2001). Third Word Political Ecology. London and New York: Routledge.

3. Dahrendorf, Ralf. (1959). Class and Class Conflict in Industrial Society. Stanford, Calif: Stanford University Press.

4. Direktori Pulau-Pulau Kecil Mengenai Pulau Romang. (2012). Tersedia pada: http://www.ppkkp3k.kkp.go.id/direktoriPulau/index.php/public_c/Pulau_info/9877.

5. Emenyeonu, Ogadimma C. \& Bahtiar, Mohamad. (2017). News Authorship and News Sources: Impacts on Environmental Coverage in The Nigerian Press. Jurnal The Messenger Vol. 9 No. 2, 110-119.

6. Fisher, S. (2001). Mengelola Konflik: Ketrampilan dan Strategi untuk Bertindak. Jakarta.

7. Hakim, Lukman. (2015). Pertambangan, Dinamika Struktur Kelas dan Kemiskinan Masyarakat Pedesaan. Studi Kasus Masyarakat Desa Sarakaman, Pulau Sebuku, Kotabaru, Kalimantan Selatan. [Tesis]. Bogor (ID): Institut Pertanian Bogor.

8. Hanafi, I. (2012). Makalah, Kebijakan Daerah Terhadap Pengelolaan Penambangan Liar di Gunung Botak, Kabupaten Buru.

9. Hasyimi, M. (2014). Perception of The Effect of Gold Mining Among Stakeholder in Health Sector in Buru District Maluku Province, 2012. J. Ekologi Kesehatan 13(1), 86-94.

10. Kinseng, R. A. (2013). Konflik-Konflik Sumber Daya Alam di Kalangan Nelayan di Indonesia. Jurnal Sodality Vol. 01 No 01.

11. Kriesberg, Louis. (1998). Constructive Conflict from Escalation to Resolution. Maryland, USA: Bowman \& Littlefield Publisher, Inc.

12. Ribot, J.C. (2003). A Theory of Access. Journal Rural Sociology Vol. 68, No. 2.

13. Satria. (2006). Krisis Ekologi Politik. Tersedia pada: http://www.korantempo.com/

14. Saptari, Holzner. (1997). Perempuan, Kerja dan Perubahan Sosial, Sebuah Pengantar Studi Perempuan. Jakarta: Kalyanamitra.

15. Shohibuddin, M. et.al. (1998). Memahami Dimensi Kemiskinan Masyarakat Adat. Jakarta.

16. Sudradjat, A. (2006). Otonomi Pengelolaan Sumber Daya Mineral dan Pengembangan Masyaraka. Bandung: LPM UNPAD. 